Submitted, accepted and published by

Fuel 250 (2019) 8-16

\title{
Improving the efficiency of Chemical Looping Combustion with coal by using ring-type internals in the fuel reactor
}

\section{Raúl Pérez-Vega, Alberto Abad*, José A. Bueno, Francisco García-Labiano, Pilar Gayán,} Luis F. de Diego, Juan Adánez

Instituto de Carboquímica (ICB-CSIC), Miguel Luesma Castán 4, 50018 Zaragoza, Spain.

* Corresponding author: A. Abad; e-mail address: abad@icb.csic.es; phone: +34 976733 977; fax: +34976733318.

\begin{abstract}
Chemical Looping Combustion (CLC) with solid fuels has been widely developed by using two interconnected fluidized beds, the fuel reactor and the air reactor, with an oxygen carrier continuously circulating between them. Experience gained in this process shows that high $\mathrm{CO}_{2}$ capture values can be reached. However, complete combustion of the fuel is not achieved, with some $\mathrm{H}_{2}, \mathrm{CO}$ and $\mathrm{CH}_{4}$ as the main unconverted compounds in the combustion products from the fuel reactor. It is believed that the combustion efficiency can be increased by improving the gassolid contact in the fuel reactor. In this work, the solids distribution in the fuel reactor was modified by using ring-type internals with the objective of enhancing the gas-solid contact. Two experimental campaigns were carried out in a $50 \mathrm{~kW}_{\text {th }}$ CLC unit burning a bituminous coal with ilmenite particles in the temperature interval of $900-1000{ }^{\circ} \mathrm{C}$. The first campaign was conducted with the original riser of the fuel reactor, which was characterized by a smooth section from bottom to top. For the second campaign, three ring-type internals were implemented in the riser in order to modify the solids distribution in the fuel reactor. The presence of the internals had a beneficial effect on the coal combustion. The major benefit was an improved oxidation of volatile matter in the form of $\mathrm{CH}_{4}$ and the full conversion of $\mathrm{H}_{2}$. As a result, the total oxygen demand decreased by $20 \%$, from $12.2 \%$ to $9.8 \%$, with the implementation of the internals.
\end{abstract}

Keywords: $\mathrm{CO}_{2}$ capture; Chemical Looping Combustion; coal; ring-type internals. 
Submitted, accepted and published by

Fuel 250 (2019) 8-16

\section{Introduction}

Carbon dioxide Capture and Storage (CCS) is a required action to drastically reduce the $\mathrm{CO}_{2}$ emissions in energy generation from fossil fuels [1]. However, the high cost of the $\mathrm{CO}_{2}$ capture process could dissuade the implementation of CCS, making difficult the achievement of the goal of the Paris Agreement, i.e. limiting the increase of the global average temperature below $2{ }^{\circ} \mathrm{C}$ by 2100 [2].

Chemical Looping Combustion (CLC) has a great potential to reduce the economic and energetic cost of $\mathrm{CO}_{2}$ capture for energy generation [3]. The CLC concept is based on the transference of oxygen from the air to the fuel by using a solid oxygen carrier, usually a metal oxide $\left(\mathrm{M}_{\mathrm{x}} \mathrm{O}_{\mathrm{y}}\right)$. In this way, fuel can be oxidized to $\mathrm{CO}_{2}$ and $\mathrm{H}_{2} \mathrm{O}$ in a nitrogen free environment. This allows pure $\mathrm{CO}_{2}$ stream to be obtained at low-cost, since after an easy condensation step, a stream highly concentrated on $\mathrm{CO}_{2}$ is ready to transport and storage [4]. In one preferred configuration, the oxygen carrier is continuously circulating between two interconnected fluidized bed reactors called fuel and air reactors [5]. Thus, an oxidized oxygen carrier is able to provide oxygen for combustion inside the fuel reactor, while it is regenerated to its initial oxidized state with the oxygen in air supplied to the air reactor.

Coal combustion via CLC has been extensively studied by means of the in-situ Gasification Chemical Looping Combustion ( $i$ G-CLC) process [6,7]; see Fig. 1. In iG-CLC, coal devolatilization and gasification happens inside the fuel reactor with $\mathrm{H}_{2} \mathrm{O}$ or $\mathrm{CO}_{2}$ fed to the fuel reactor; see reaction $\mathrm{R} 1$. Then, gasification products are oxidized by the oxygen carrier to $\mathrm{CO}_{2}$ and $\mathrm{H}_{2} \mathrm{O}$; reaction $\mathrm{R} 2$. The reduced oxygen carrier, $\mathrm{M}_{\mathrm{x}} \mathrm{O}_{\mathrm{y}-1}$, is transported to the air reactor where it is regenerated with oxygen in air -reaction R3- to be later used in the fuel reactor again.

Fuel reactor:

Coal $+\mathrm{n} \mathrm{H}_{2} \mathrm{O} / \mathrm{CO}_{2} \rightarrow$ Gasification products $\left(\mathrm{CO}, \mathrm{H}_{2}, \mathrm{CH}_{4}\right.$, etc.)

$n \mathrm{M}_{\mathrm{x}} \mathrm{O}_{\mathrm{y}}+$ Gasification products $\left(\mathrm{CO}, \mathrm{H}_{2}, \mathrm{CH}_{4}\right.$, etc. $) \rightarrow \mathrm{n} \mathrm{M}_{\mathrm{x}} \mathrm{O}_{\mathrm{y}-1}+\mathrm{p} \mathrm{CO}_{2}+\mathrm{q} \mathrm{H}_{2} \mathrm{O}$ 
Submitted, accepted and published by

Fuel 250 (2019) 8-16

Air reactor:

$$
\begin{aligned}
& 2 \mathrm{M}_{\mathrm{x}} \mathrm{O}_{\mathrm{y}-1}+\mathrm{O}_{2} \rightarrow 2 \mathrm{M}_{\mathrm{x}} \mathrm{O}_{\mathrm{y}} \\
& \mathrm{C}+\mathrm{O}_{2} \rightarrow \mathrm{CO}_{2}
\end{aligned}
$$

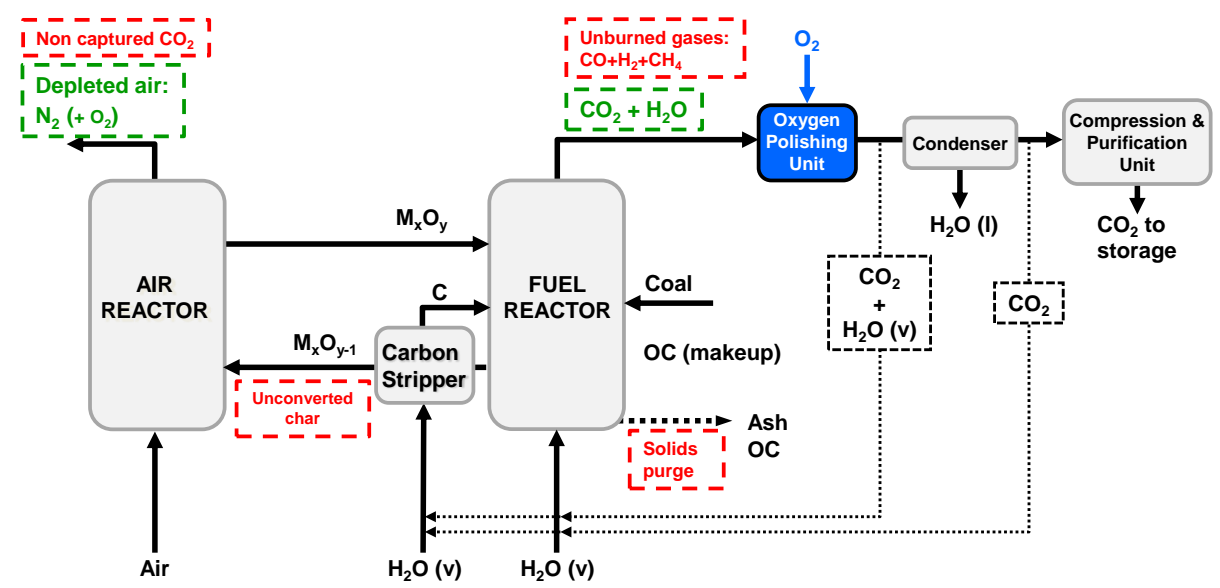

Fig. 1. Scheme of $i \mathrm{G}-\mathrm{CLC}$ process for coal combustion.

There is great experience around worldwide operating continuous CLC units with solid fuels, which has driven to significant advances on $i \mathrm{G}-\mathrm{CLC}$ [7]. In most cases, low cost materials, such as natural ores or industrial wastes, have been used as oxygen carriers. Despite their lower reactivity compared to synthetic materials, the use of low cost materials is popular due to the expected high make-up flow to replace the oxygen carrier lost together the required ash purge.

Coal gasification has been identified as the limiting step during the fuel conversion in the fuel reactor [8]. As a consequence, unconverted char particles could reach the air reactor together the oxygen carrier stream. Then, they will burn to $\mathrm{CO}_{2}$-reaction $\mathrm{R} 4-$ with the corresponding decrease in the $\mathrm{CO}_{2}$ capture efficiency. This issue has been solved by including a carbon separation unit between the fuel and air reactors [9-12], reaching $\mathrm{CO}_{2}$ capture values close to $100 \%$.

Another relevant issue in $i \mathrm{G}-\mathrm{CLC}$ is the appearance of unburned gases, mainly $\mathrm{CO}, \mathrm{H}_{2}$ and $\mathrm{CH}_{4}$, at the fuel reactor outlet [7]. Lyngfelt and Leckner [13] proposed to oxidize them in an oxygen 
Submitted, accepted and published by

Fuel 250 (2019) 8-16

polishing unit with pure oxygen; see Fig. 1. But this implies an economic and energy penalty on the overall process. The optimization of the operating conditions can improve the combustion efficiency, but a relevant fraction of unburnt products is still present in the $\mathrm{CO}_{2}$ stream [11]. Some options have been suggested to increase the combustion efficiency of the process, including:

- Using more reactive oxygen carrier materials was proposed as one of the more efficient way to improve the combustion efficiency [14]. In this sense, the performance of synthetic materials overcomes those of natural ores. Thus, the use of a highly reactive $\mathrm{Cu}$-based material developed by ICB-CSIC [15] has been tested in a $25 \mathrm{~kW}_{\text {th }}$ CLC unit at TUHH, improving the combustion efficiency achieved with ilmenite [16]. In this case, materials easily separable from the ash particles would be advised, e.g. using the magnetic properties of the Mn-Fe redox system for the design of oxygen carriers [17] or supporting materials [18].

O Implementing a secondary fuel reactor [19]. Thus, the combustion efficiency has been improved by splitting the solids in the fuel reactor in two compartments [20,21]. In this sense, the use of up to 5 compartments has been proposed [22].

o Recirculating unburnt products to the fuel reactor [23]. Different alternatives have been modelled, the best option being the recirculation of a fraction of the exhaust gases to the carbon stripper [24].

O Improving the gas-solid contact in the fuel reactor [25]. Experimental works in cold flow models showed that the use of ring-type internals in the fuel reactor modifies the distribution of solids to make it more homogeneous with height $[25,26]$. At low gas velocities characteristics of the bubbling regime, the fuel reactor can be considered as one reactor split in different compartments by the internal as it was discussed above [21,22]. In this case, the fuel reactor is characterized by a counter-flow of falling solids and ascending gas $[25,26]$. However, at high velocities the solids entrainment is promoted, but the core-nucleus structure in the fast fluidization regime is disturbed [27]. It would be expected that the gas-solid contact could be promoted in the dilute 
Submitted, accepted and published by

Fuel 250 (2019) 8-16

region. Theoretical calculations showed that the modification of the solids distribution in the fuel reactor by using ring-type internals can reduce the amount of unburnt products by $35 \%$ [24], but not experimental confirmation has been done.

The objective of this work is to assess the effect of the presence of ring-type internals in the fuel reactor on performance of the $i \mathrm{G}$-CLC process for coal. Two experimental campaigns were conducted in a continuously operated CLC pilot plant for solid fuels. The first campaign was made with the original riser of the fuel reactor, which is characterized by a smooth section from the bottom to top. For the second campaign, three ring-type internals were implemented in the fuel reactor in order to modify the solids distribution. Experimental conditions were selected in order to analyse the effect of the presence of ring-type internals on the $\mathrm{CO}_{2}$ capture and the combustion efficiency of the CLC process with coal.

\section{Experimental}

\subsection{Materials}

The oxygen carrier used in this work was Norwegian ilmenite from Titania A/S Company. Oxygen carrier particles, in the $0.1-0.3 \mathrm{~mm}$ size, were exposed to thermal treatment in air at $950{ }^{\circ} \mathrm{C}$ for 2 hours as a pre-oxidation stage, since the material was received in its reduced form, i.e. $\mathrm{FeTiO}_{3}$. Table 1 shows the main physicochemical characteristics of activated ilmenite particles [28]. Ilmenite has been extensively used as oxygen carrier in CLC with coal, and can be considered a reference material [7].

A Russian bituminous coal from the "Taldinsky" mine was used as fuel. Coal was crushed and sieved to obtain particles in the $0.1-0.3 \mathrm{~mm}$ interval. Table 1 shows the proximate and ultimate analyses of the coal. The lower heating value is $\mathrm{LHV}=26640 \mathrm{~kJ} / \mathrm{kg}$ and the oxygen demand for its combustion is $\Omega_{\mathrm{sf}}=2.0 \mathrm{~kg}$ of oxygen per $\mathrm{kg}$ of coal. 
Submitted, accepted and published by

Fuel 250 (2019) 8-16

Table 1. Main properties of ilmenite particles and "Taldinsky" bituminous coal.

\begin{tabular}{llll}
\hline Ilmenite [28] & & \multicolumn{2}{l}{ "Taldinsky" bituminous coal (wt\%) [29] } \\
\hline Main XRD phases & $\mathrm{Fe}_{2} \mathrm{TiO}_{5}$ & Moisture & 5.8 \\
& $\mathrm{Fe}_{2} \mathrm{O}_{3}$ & Ash & 10.1 \\
& $\mathrm{TiO}_{2}$ & Volatile matter & 32.0 \\
Crushing strength (N) & 2.0 & Fixed carbon & 52.1 \\
Oxygen transport capacity, $R_{O C}(\%)$ & 3.9 & $\mathrm{C}$ & 65.8 \\
Skeletal density $\left(\mathrm{kg} / \mathrm{m}^{3}\right)$ & 4200 & $\mathrm{H}$ & 4.0 \\
Porosity (\%) & 18.0 & $\mathrm{~N}$ & 2.0 \\
& & $\mathrm{~S}$ & 0.5 \\
\hline
\end{tabular}

\subsection{Chemical Looping Combustion facility}

The experimental facility was a CLC pilot plant for solid fuels located at ICB-CSIC [30]; see Fig. 2(a). This facility was designed to operate in both $i \mathrm{G}-\mathrm{CLC}$ and CLOU modes. The nominal thermal power was $20 \mathrm{~kW}_{\text {th }}$ for $i \mathrm{G}-\mathrm{CLC}$ mode and $50 \mathrm{~kW}_{\text {th }}$ for CLOU mode. In this work, the unit was operated in $i \mathrm{G}-\mathrm{CLC}$ mode by using ilmenite as oxygen carrier.

The CLC unit mainly consists of two interconnected circulating fluidized beds, being the fuel and air reactors, and one carbon stripper being a bubbling fluidized bed. The fuel reactor is designed with two parts: bottom bed ( $0.10 \mathrm{~m}$ inner diameter, $1.2 \mathrm{~m}$ height $)$ and upper part $(0.08 \mathrm{~m}$ inner diameter, $2.8 \mathrm{~m}$ tall). The gas velocity in both sections of the fuel reactor is the adequate to operate in the turbulent regime, supporting the required solids circulation rate in the unit. Originally, the riser of the fuel reactor was designed with a regular internal side [30]. Following, geometrical constrictions were implemented inside in order to increase the amount of solids in the dilute zone of the fuel reactor to enhance the gas-solid contact. Thus, three ring-type internals were placed throughout of the riser, maintaining a distance between two consecutive rings of $0.7 \mathrm{~m}$; see Fig. 2(b). These internals were designed according with results obtained by Guío-Pérez et al. [26]. The rings were wedge-shaped designed, with the opening section being the $60 \%$ of the reactor crosssection; see Fig. 2(c). 
Submitted, accepted and published by

Fuel 250 (2019) 8-16
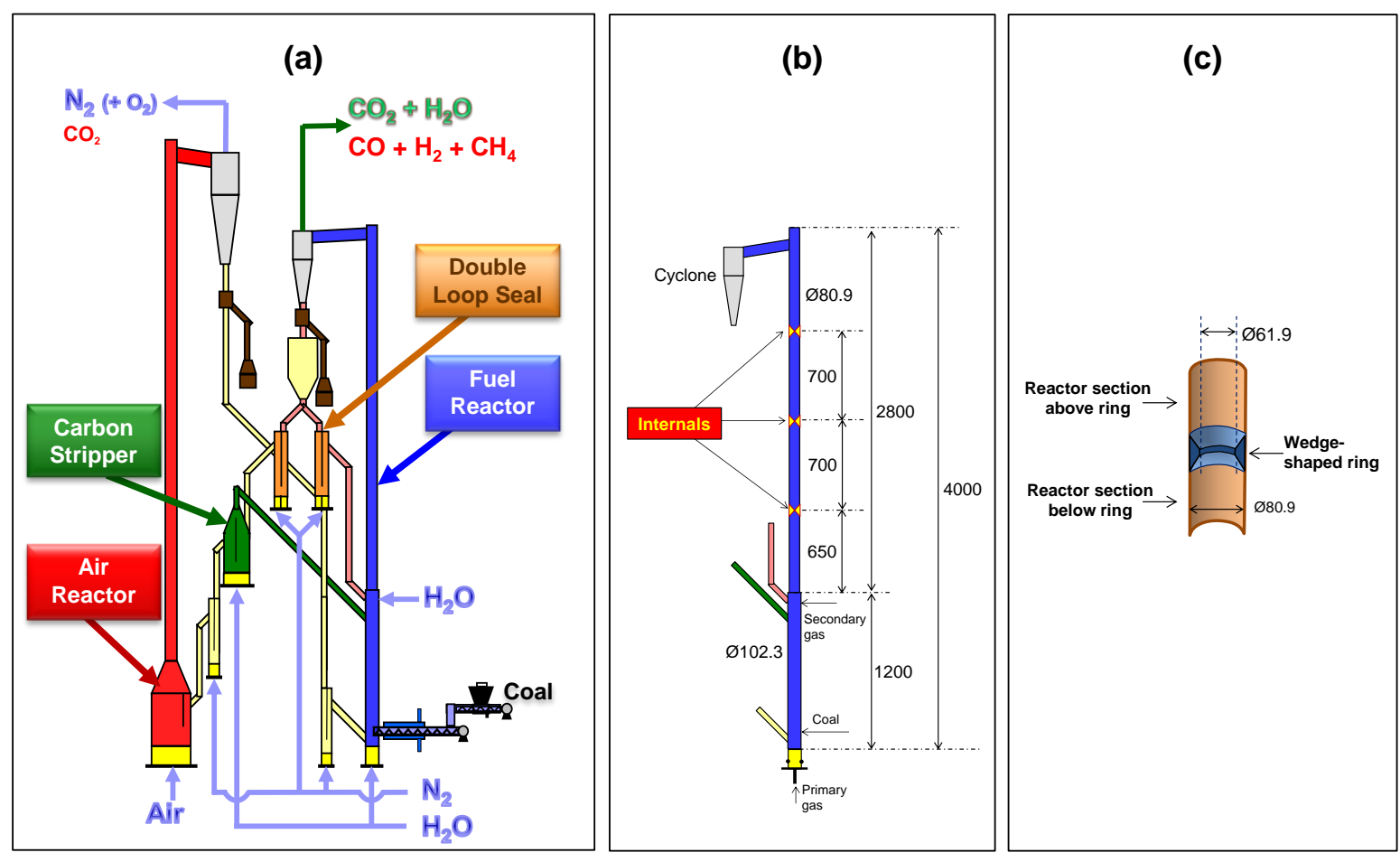

Fig. 2. (a) Layout of the $50 \mathrm{~kW}_{\text {th }}$ CLC facility [30]; (b) detail of the fuel reactor with indication of position of ring-type internals; (c) detail of section of one ring-type internal.

Coal is fed at the bottom of the fuel reactor through a double screw feeder system to maximize the contact between the volatile matter and the oxygen carrier particles. The CLC unit is not expected to be auto-thermal due to heat losses associated to the unit size. Then, the fuel reactor, air reactor, carbon stripper, and loop seals are heated by separate furnaces. Different thermocouples in the fuel and air reactors, as well as in the carbon stripper, have been included in order to monitor the temperature of these reactors. Likewise, several differential pressure gauges are distributed throughout CLC facility in order to measure the pressure drop between different points of the unit. This allows solids inventory to be estimated in each reactor, which is useful to determine the specific solids inventory in the fuel reactor. Two solids diverter valves are used to measure directly the solids flux exiting from both the fuel and air reactors. The solids circulation flow rate could be modified by acting on the double loop seal (D-LS). Thus, the solids exiting from the fuel reactor could be divided in two streams: (1) the main stream to the carbon stripper, corresponding to the 
Submitted, accepted and published by

Fuel 250 (2019) 8-16

circulating solids between the air and fuel reactors; and (2) solids internally recirculated to the fuel reactor. More detailed information about the design of the CLC unit can be found elsewhere [30]. The concentration of $\mathrm{CO}, \mathrm{CO}_{2}, \mathrm{H}_{2}$, and $\mathrm{CH}_{4}$ in the fuel reactor outlet stream and $\mathrm{CO}_{2}$ and $\mathrm{O}_{2}$ from the air reactor was continuously recorded by specific gas analysers. The concentrations of the Cbased gases are measured using a non-dispersive infrared analyzer (Siemens Ultramat 23), whereas a thermal conductivity detector (Maihak S710/THERMOR) and a paramagnetic analyzer (Siemens 23/Oxymat 6) are used to measure the $\mathrm{H}_{2}$ and $\mathrm{O}_{2}$ concentrations, respectively.

\subsection{Experimental conditions}

Both the fuel reactor and the carbon stripper were fluidized by $\mathrm{H}_{2} \mathrm{O}$, which acts as fluidizing medium and gasifying agent. The steam flow in the carbon stripper was set at $5 \mathrm{Nm}^{3} / \mathrm{h}$, which supposes an inlet gas velocity in the carbon stripper of $0.35 \mathrm{~m} / \mathrm{s}$ at $950{ }^{\circ} \mathrm{C}$. The total steam flow fed to the fuel reactor was maintained at $10 \mathrm{Nm}^{3} / \mathrm{h}$. In most of the tests this flow was divided, being introduced $7 \mathrm{Nm}^{3} / \mathrm{h}$ at the bottom part and $3 \mathrm{Nm}^{3} / \mathrm{h}$ as secondary gas; see Fig. 2(b). In some tests, the steam total flow $\left(10 \mathrm{Nm}^{3} / \mathrm{h}\right)$ was only fed at the bottom part. The gas velocity at the bottom part was $1.2-1.8 \mathrm{~m} / \mathrm{s}$, while it was about $5 \mathrm{~m} / \mathrm{s}$ at the upper part. Note that gas flow to the carbon stripper is also added to the gas flow in the upper part of the fuel reactor.

Constant air flow of $40 \mathrm{Nm}^{3} / \mathrm{h}$ was supplied in the air reactor in order to act as fluidizing and oxidizing agent, corresponding to a gas velocity of $0.7 \mathrm{~m} / \mathrm{s}$ at the bottom and of $6.0 \mathrm{~m} / \mathrm{s}$ at upper of this reactor. Nitrogen was selected as fluidizing medium into all loop-seals of the facility.

In total, 14 tests at steady state were carried out in two experimental campaigns: (1) the first one corresponding to a reference Series $\mathrm{R}$ (tests 1-6) by using the original riser of the fuel reactor without internals; and (2) the second campaign corresponding to Series I-1, I-2 and I-3 (tests 7-14) where the ring-type internals were implemented inside the riser of the fuel reactor; see Table 2. Series I-1 was characterized by a low amount of solids in the fuel reactor, mainly being in the bottom part. Then, the transference of solids to the upper part was enhanced either by increasing the 
Submitted, accepted and published by

Fuel 250 (2019) 8-16

solids inventory (Series I-2) or by increasing the gas velocity in the bottom part (Series I-3).

Table 2. Operating conditions and evaluating parameters for the experimental campaigns conducted in the CLC unit using ilmenite as oxygen carrier.

\begin{tabular}{|c|c|c|c|c|c|c|c|c|c|}
\hline Internals & Series & Test & $\begin{array}{c}T_{F R, \text { bottom }} \\
\left({ }^{\circ} \mathrm{C}\right)\end{array}$ & $\begin{array}{c}T_{\text {FR,upper }} \\
\left({ }^{\circ} \mathrm{C}\right)\end{array}$ & $\begin{array}{c}u_{g, F R b o t t o m} \\
(\mathrm{~m} / \mathrm{s})\end{array}$ & $\begin{array}{l}\text { Power } \\
\left(\mathrm{kW}_{\mathrm{th}}\right)\end{array}$ & $\begin{array}{c}\dot{m}_{O C} \\
(\mathrm{~kg} / \mathrm{h})\end{array}$ & $\begin{array}{c}\phi \\
(-)\end{array}$ & $\begin{array}{c}m_{F R}^{*} \\
\left(\mathrm{~kg} / \mathrm{MW}_{\mathrm{th}}\right)\end{array}$ \\
\hline \multirow{6}{*}{ NO } & \multirow{6}{*}{$\mathrm{R}$} & 1 & 905 & 910 & 1.0 & 14.0 & 125 & 1.3 & 520 \\
\hline & & 2 & 960 & 955 & 1.1 & 14.0 & 125 & 1.3 & 535 \\
\hline & & 3 & 970 & 972 & 1.1 & 14.0 & 125 & 1.3 & 485 \\
\hline & & 4 & 985 & 990 & 1.2 & 14.0 & 125 & 1.3 & 475 \\
\hline & & 5 & 990 & 988 & 1.2 & 14.0 & 125 & 1.3 & 400 \\
\hline & & 6 & 1000 & 985 & 1.2 & 14.0 & 125 & 1.3 & 325 \\
\hline \multirow{2}{*}{ YES } & \multirow{2}{*}{ I-1 } & 7 & 910 & 965 & 1.0 & 12.5 & 80 & 0.9 & 270 \\
\hline & & 8 & 970 & 1030 & 1.1 & 12.5 & 80 & 0.9 & 225 \\
\hline \multirow{4}{*}{ YES } & \multirow{4}{*}{$\mathrm{I}-2$} & 9 & 910 & 930 & 1.0 & 14.8 & 140 & 1.3 & 420 \\
\hline & & 10 & 970 & 967 & 1.1 & 14.8 & 140 & 1.3 & 480 \\
\hline & & 11 & 990 & 980 & 1.2 & 14.8 & 140 & 1.3 & 400 \\
\hline & & 12 & 1000 & 985 & 1.2 & 14.8 & 140 & 1.3 & 435 \\
\hline \multirow{2}{*}{ YES } & \multirow{2}{*}{ I-3 } & 13 & 950 & 975 & 1.7 & 17.0 & 115 & 1.0 & 320 \\
\hline & & 14 & 970 & 990 & 1.8 & 17.0 & 115 & 1.0 & 260 \\
\hline
\end{tabular}

Experimental conditions were selected in order to perform a proper comparison of the $\mathrm{CO}_{2}$ capture and the combustion efficiency obtained with and without internals. For this, it was considered that the fuel reactor temperature was mainly affecting to the $\mathrm{CO}_{2}$ capture, while the solids circulation flow rate and the solids inventory in the fuel reactor were the main operating conditions affecting to the combustion efficiency [11]. Thus, the fuel reactor temperature was varied in the $900-1000{ }^{\circ} \mathrm{C}$ interval. The carbon stripper temperature was maintained at a value similar than in the fuel reactor. The air reactor temperature was maintained at $950{ }^{\circ} \mathrm{C}$. Solids circulation rate, $\dot{m}_{O C}$, was varied in the $55-200 \mathrm{~kg} / \mathrm{h}$ interval by acting on the D-LS. The effect of $\dot{m}_{O C}$ was evaluated by means of the oxygen carrier to fuel ratio, $\phi$, defined as the flow of oxygen available inside the fuel reactor divided by the flow of oxygen required to achieve complete fuel combustion [7]. The specific solids inventory in the fuel reactor, $m_{F R}^{*}$, was varied between 225 and $535 \mathrm{~kg} / \mathrm{MW}_{\mathrm{th}}$, which was estimated 
Submitted, accepted and published by

Fuel 250 (2019) 8-16

by means of the measurement of the pressure drop in the fuel reactor [11].

\subsection{Evaluating parameters}

Performance on $i \mathrm{G}-\mathrm{CLC}$ process was assessed through four evaluating features: solid fuel conversion, $\mathrm{CO}_{2}$ capture efficiency, combustion efficiency in the fuel reactor and total oxygen demand, following the standardized nomenclature proposed by Adánez et al. [7] and calculated from Eqs. (1)-(4).

$X_{s f}=\frac{\text { carbon in gases from FR and AR }}{\text { carbon in solid fuel }}=\frac{\left(F_{\mathrm{CO}_{2}}+F_{C O}+F_{\mathrm{CH}_{4}}\right)_{F R}+F_{\mathrm{CO}_{2}, \mathrm{AR}}}{\left(\frac{1000}{12}\right) \cdot \dot{m}_{s f} \cdot x_{C}}$

$\eta_{C C}=\frac{\text { carbon in gases from FR }}{\text { carbon in gases from FR and AR }}=\frac{\left(F_{\mathrm{CO}_{2}}+F_{C O}+F_{C H_{4}}\right)_{F R}}{\left(F_{\mathrm{CO}_{2}}+F_{C O}+F_{\mathrm{CH}_{4}}\right)_{F R}+F_{\mathrm{CO}_{2}, \mathrm{AR}}}$

$\eta_{c o m b, F R}=1-\frac{\text { ox. needed to burn unconverted gases }}{\text { ox. demanded by fuel converted in FR }}=1-\frac{\left[F_{H_{2}}+F_{C O}+4 F_{C H_{4}}\right]_{F R}}{\left[\frac{1000}{16}\right] \dot{m}_{s f} \Omega_{s f}-2\left[F_{C O_{2}, A R}+F_{C, \text { elut }}\right]}$

$\Omega_{T}=\frac{\text { oxygen needed to burn unconverted gases }}{\text { oxygen needed to burn solid fuel }}=\frac{\left(F_{C O}+F_{H_{2}}+4 F_{C H_{4}}\right)_{F R}}{\left(\frac{1000}{16}\right) \cdot \dot{m}_{s f} \cdot \Omega_{s f}}$

The solid fuel conversion, $X_{s f}$, represents the fraction of carbon in solid fuel that is converted to gaseous compounds in the CLC unit, i.e. both in the fuel and air reactors. Carbon flow no detected in gaseous streams is assumed to be present in the unconverted char particles not recovered by the fuel reactor cyclone, being considered as elutriated carbon, $F_{C, \text { elut }}$. The $\mathrm{CO}_{2}$ capture efficiency, $\eta_{C C}$, represents the fraction of carbon in gases actually exiting from the fuel reactor. The carbon flow exiting from the fuel reactor depends on the char being gasified in the fuel reactor, which is evaluated through the fraction of carbon in char converted in the fuel reactor, $x_{c h a r, F R}$, calculated by Eq. (5). The generated gases in the fuel reactor, both in volatile mater and gasification products, must be oxidized to $\mathrm{CO}_{2}$ and $\mathrm{H}_{2} \mathrm{O}$ by reacting with oxygen carrier particles. The degree of oxidation of these gases is evaluated with the combustion efficiency in the fuel reactor, $\eta_{\text {comb,FR. Often, this }}$ parameter is expressed as the oxygen demand in the fuel reactor, i.e. $\Omega_{\mathrm{FR}}=1-\eta_{\mathrm{comb}, \mathrm{FR}}$. 
Submitted, accepted and published by

Fuel 250 (2019) 8-16

Complementary, the total oxygen demand, $\Omega_{\mathrm{T}}$, describes the combustion efficiency by an intuitive definition: the fraction of oxygen required to fully oxidize unburnt gases from fuel reactor with respect to the stoichiometric oxygen required to fully oxidize the fuel.

$x_{c h a r, F R}=\frac{\text { fixed carbon converted in FR }}{\text { fixed carbon in solid fuel }}=\frac{\left(F_{C O_{2}}+F_{C O}+F_{C H_{4}}\right)_{F R}-\left[\left(\frac{1000}{12}\right) \cdot \dot{m}_{s f} \cdot\left(x_{C}-x_{f c}\right)\right]}{\left[\left(\frac{1000}{12}\right) \cdot \dot{m}_{s f} \cdot x_{f c}\right]}$

The gas flow of every gaseous compound, $F_{i}$, was calculated from the measured gas concentrations and the total gas flow exiting from each reactor, which was determined by means of a $\mathrm{N}_{2}$ balance following the methodology described in previous works $[11,17,28]$.

\section{Results and discussion}

Two experimental campaigns burning "Taldinsky" coal with ilmenite was ongoing in the CLC unit. A total of $50 \mathrm{~h}$ of continuous circulation of solids at hot conditions were gathered, of which $28 \mathrm{~h}$ corresponded to combustion tests. Table 3 shows the values calculated for the evaluating parameters for the 14 tests performed in the CLC unit. Tests in Series R were performed with the original fuel reactor without ring-type internals, while three ring-type internals were implemented in the fuel reactor for the Series I-1 to I-3.

In general, high solid fuel conversions, in the $84-98 \%$ interval with an average value of $92 \%$, were found regardless of the implementation of the internals inside the fuel rector. This supposes an average percentage of elutriated coal of $8 \%$, which is relatively low compared to results found in the literature [7], and agrees with the range of values observed in a previous work burning other bituminous coal [11]. Following, the evaluating parameters will be discussed to assess the effect of the presence of ring-type internals on the performance of the $i \mathrm{G}-\mathrm{CLC}$ process. 
Submitted, accepted and published by

Fuel 250 (2019) 8-16

Table 3. Evaluating parameters, gas concentration at the fuel reactor, contribution of unconverted gases to the total oxygen demand, and methane conversion.

\begin{tabular}{|c|c|c|c|c|c|c|c|c|c|c|c|c|c|c|}
\hline \multirow[t]{2}{*}{ Series } & \multirow[t]{2}{*}{ Test } & \multirow{2}{*}{$\begin{array}{c}X_{s f} \\
\%\end{array}$} & \multirow{2}{*}{$\begin{array}{c}\eta_{\mathrm{CC}} \\
\%\end{array}$} & \multirow{2}{*}{$\begin{array}{c}x_{\text {char }, F R} \\
\%\end{array}$} & \multirow{2}{*}{$\begin{array}{c}\Omega_{\mathrm{FR}} \\
\%\end{array}$} & \multirow{2}{*}{$\begin{array}{c}\Omega_{\mathrm{T}} \\
\%\end{array}$} & \multicolumn{4}{|c|}{$\begin{array}{l}\text { Gas concentration at the FR } \\
\text { outlet }\left(\% \text {, dry and } \mathrm{N}_{2} \text {-free) }\right.\end{array}$} & \multicolumn{3}{|c|}{$\begin{array}{l}\text { Contribution to the } \\
\qquad \Omega_{\mathrm{T}}(\%)\end{array}$} & \multirow{2}{*}{$\begin{array}{c}X_{\mathrm{CH}_{4}} \\
\%\end{array}$} \\
\hline & & & & & & & $\mathrm{CO}_{2}$ & $\mathrm{CO}$ & $\mathrm{H}_{2}$ & $\mathrm{CH}_{4}$ & $\mathrm{CO}$ & $\mathrm{H}_{2}$ & $\mathrm{CH}_{4}$ & \\
\hline \multirow{6}{*}{$\mathrm{R}$} & 1 & 92.3 & 70.4 & 55.8 & 16.4 & 11.9 & 77.9 & 12.8 & 3.4 & 5.9 & 32.0 & 8.5 & 59.6 & 50.3 \\
\hline & 2 & 95.5 & 84.2 & 75.3 & 14.7 & 12.1 & 80.9 & 11.5 & 2.8 & 4.7 & 34.9 & 8.6 & 56.5 & 51.9 \\
\hline & 3 & 96.1 & 88.2 & 80.8 & 14.1 & 12.4 & 81.4 & 11.4 & 2.7 & 4.5 & 34.4 & 8.3 & 54.8 & 50.8 \\
\hline & 4 & 92.9 & 90.0 & 79.3 & 13.3 & 11.8 & 81.4 & 11.6 & 2.9 & 4.1 & 35.2 & 8.7 & 49.7 & 55.9 \\
\hline & 5 & 93.7 & 92.0 & 82.6 & 13.9 & 12.6 & 81.0 & 11.9 & 2.7 & 4.4 & 37.1 & 8.4 & 54.5 & 51.8 \\
\hline & 6 & 92.9 & 92.3 & 82.0 & 13.9 & 12.5 & 80.6 & 12.3 & 2.7 & 4.3 & 38.2 & 8.4 & 53.4 & 52.9 \\
\hline \multirow{2}{*}{ I-1 } & 7 & 86.5 & 77.7 & 58.6 & 24.6 & 17.4 & 71.2 & 18.3 & 3.9 & 6.6 & 37.8 & 8.1 & 54.1 & 44.7 \\
\hline & 8 & 98.0 & 93.3 & 89.2 & 20.1 & 18.6 & 60.8 & 24.8 & 4.0 & 4.5 & 53.2 & 8.5 & 38.3 & 46.7 \\
\hline \multirow{4}{*}{$\mathrm{I}-2$} & 9 & 94.0 & 72.6 & 59.9 & 13.9 & 10.0 & 80.8 & 14.5 & 0.1 & 4.6 & 43.9 & 0.3 & 55.8 & 60.5 \\
\hline & 10 & 91.5 & 77.8 & 63.6 & 13.4 & 10.0 & 82.0 & 11.9 & 1.7 & 4.4 & 38.3 & 5.4 & 56.3 & 60.4 \\
\hline & 11 & 86.7 & 80.7 & 64.1 & 13.0 & 9.7 & 82.7 & 11.1 & 2.0 & 4.3 & 36.8 & 6.6 & 56.6 & 61.3 \\
\hline & 12 & 86.3 & 80.8 & 63.8 & 12.7 & 9.5 & 82.4 & 11.6 & 2.0 & 3.9 & 39.5 & 6.9 & 53.6 & 64.3 \\
\hline \multirow{2}{*}{ I-3 } & 13 & 83.8 & 78.4 & 56.7 & 14.8 & 10.3 & 76.5 & 19.5 & 0.0 & 4.0 & 55.1 & 0.0 & 44.9 & 67.4 \\
\hline & 14 & 96.2 & 81.2 & 72.4 & 13.4 & 10.8 & 79.3 & 17.2 & 0.0 & 3.5 & 55.1 & 0.0 & 44.9 & 65.8 \\
\hline
\end{tabular}

\section{1. $\mathrm{CO}_{2}$ capture efficiency}

Fig. 3 shows the variation of the $\mathrm{CO}_{2}$ capture as a function of the fuel reactor temperature for the four experimental series shown in Table 2. An increase of the $\mathrm{CO}_{2}$ capture efficiency with temperature was observed in all cases, which is related to the calculated increase in the fraction of

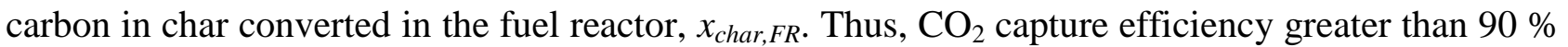
was achieved at a fuel reactor temperature higher than $980-990{ }^{\circ} \mathrm{C}$ in Series $\mathrm{R}$ and $\mathrm{I}-1$, but lower values were found for Series I-2 and I-3.

During the experimental campaign without internals inside the fuel reactor, Series R, a maximum $\mathrm{CO}_{2}$ capture value of $92.3 \%$ was obtained at $1000{ }^{\circ} \mathrm{C}$. This value is still far from those obtained in a $100 \mathrm{~kW}_{\text {th }}$ CLC unit at Chalmers $\left(\eta_{\mathrm{CC}} \sim 99 \%\right)$, where the char separation was highly efficient due to advanced design of the carbon stripper, with four compartment individually fluidized, and the lower size of coal particles $(\sim 0.04 \mathrm{~mm})$ [9]. Nevertheless, the fraction of char converted in the fuel reactor was relatively high because the solid fuel conversion, $X_{s f}$, was significantly high, i.e. the fraction of char not recovered by the cyclone was low. The fraction of char converted in the fuel reactor could 
Submitted, accepted and published by

Fuel 250 (2019) 8-16

have an effect on the combustion efficiency in the fuel reactor, and will be discussed later.

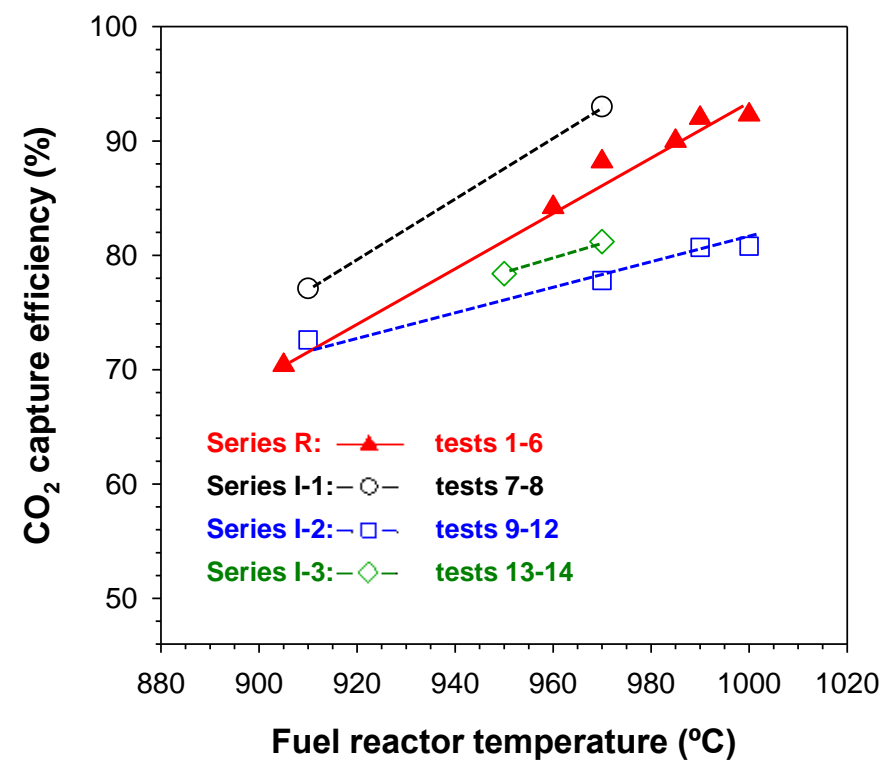

Fig. 3. $\mathrm{CO}_{2}$ capture efficiency as a function of the fuel reactor temperature for tests conducted without internals (closed symbols) and with internals (open symbols).

Some differences on the $\mathrm{CO}_{2}$ capture efficiencies were observed when the ring-type internals were implemented inside the fuel reactor (Series I-1, I-2 and I-3), which can be justified by differences in the fluid dynamics and solids distribution in the fuel reactor; see Table 4 and Fig. 4 . Higher $\mathrm{CO}_{2}$ capture values were obtained in Series I-1 than in Series R. In this case, a low amount of solids was present in the whole fuel reactor, corresponding to values of the specific solids inventory about 250 $\mathrm{kg} / \mathrm{MW}_{\text {th }}$. As a consequence, the fraction of solids in the upper part of the fuel reactor was low, and a high temperature profile in the fuel reactor was found; see Table 2. The high temperature in the upper part of the fuel reactor could promote the char conversion, thus achieving higher values of the $\mathrm{CO}_{2}$ capture. 
Submitted, accepted and published by

Fuel 250 (2019) 8-16
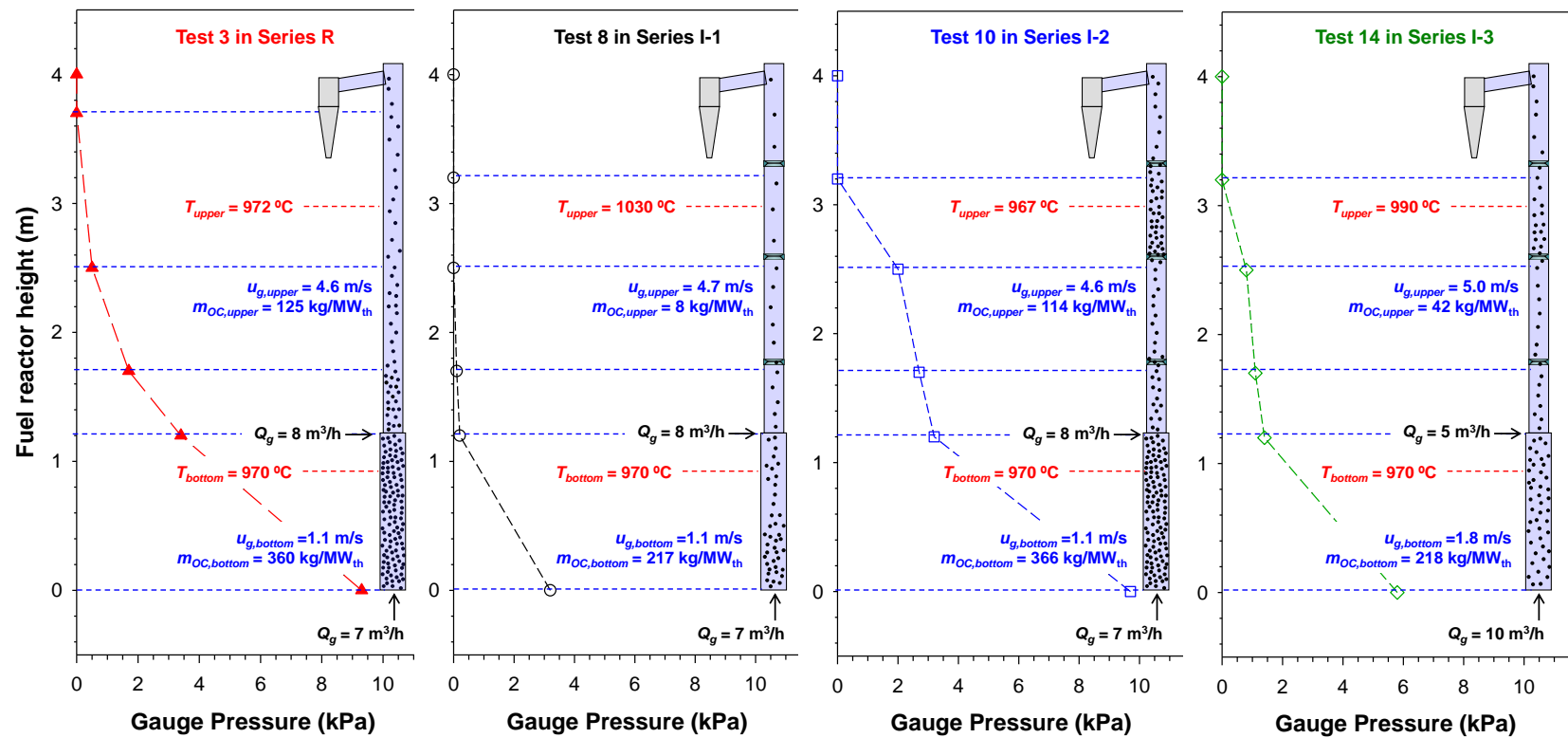

Fig. 4. Pressure profile in the fuel reactor in tests at $970{ }^{\circ} \mathrm{C}$ for selected test in Series R, I-1, I-2 and I-3. The gas velocity and distribution of solids between the bottom and upper part is also indicated. The gas flow at $1.2 \mathrm{~m}$ includes secondary flow and gas from carbon stripper.

Table 4. Specific solids inventory and distribution of the ilmenite particles in the fuel reactor, as well as temperature difference between the bottom and the upper parts.

\begin{tabular}{|c|c|c|c|c|c|c|c|c|}
\hline \multirow[t]{2}{*}{ Series } & \multirow[t]{2}{*}{ Test } & \multirow{2}{*}{$\begin{array}{c}\Delta T_{\text {upper-bottom }} \\
\quad\left({ }^{\circ} \mathrm{C}\right)\end{array}$} & \multicolumn{2}{|c|}{$\Delta P_{F R}(\mathrm{kPa})$} & \multicolumn{2}{|c|}{$m_{F R}^{*}\left(\mathrm{~kg} / \mathrm{MW}_{\mathrm{th}}\right)$} & \multicolumn{2}{|c|}{$\begin{array}{l}\text { Distribution of solids in the } \\
\text { fuel reactor }(\%)\end{array}$} \\
\hline & & & Bottom & Upper & Bottom & Upper & Bottom & Upper \\
\hline \multirow{6}{*}{$\mathrm{R}$} & 1 & +5 & 6.4 & 3.4 & 392 & 128 & 75 & 25 \\
\hline & 2 & -5 & 6.6 & 3.4 & 405 & 130 & 76 & 24 \\
\hline & 3 & +2 & 5.9 & 3.3 & 360 & 125 & 74 & 26 \\
\hline & 4 & +5 & 5.1 & 4.3 & 311 & 164 & 65 & 35 \\
\hline & 5 & -2 & 4.8 & 2.9 & 290 & 110 & 72 & 28 \\
\hline & 6 & -15 & 3.5 & 3.0 & 210 & 115 & 65 & 35 \\
\hline \multirow{2}{*}{$\mathrm{I}-1$} & 7 & +55 & 3.9 & 0.3 & 255 & 15 & 95 & 5 \\
\hline & 8 & +60 & 3.0 & 0.2 & 217 & 8 & 96 & 4 \\
\hline \multirow{4}{*}{$\mathrm{I}-2$} & 9 & +20 & 5.5 & 3.2 & 310 & 110 & 73 & 27 \\
\hline & 10 & -3 & 6.5 & 3.2 & 366 & 114 & 76 & 24 \\
\hline & 11 & -10 & 5.5 & 2.6 & 310 & 90 & 77 & 23 \\
\hline & 12 & -15 & 6.2 & 2.4 & 350 & 85 & 80 & 20 \\
\hline \multirow{2}{*}{$\mathrm{I}-3$} & 13 & +25 & 5.2 & 1.9 & 260 & 60 & 81 & 19 \\
\hline & 14 & +20 & 4.4 & 1.4 & 218 & 42 & 83 & 17 \\
\hline
\end{tabular}


Submitted, accepted and published by

Fuel 250 (2019) 8-16

On the contrary, lower $\mathrm{CO}_{2}$ capture rates were observed in Series I-2, where the solids inventory in the CLC unit was increased compared to Series I-1. In this case, the solids distribution was significantly varied from the reference case without internals, i.e. Series R; but in both Series R and I-2 a homogeneous temperature in the whole fuel reactor was found. Fig. 4 shows that a gradual decrease in the gauge pressure with the reactor height was observed in absence of internals, which corresponds to a gradual decrease in the solids concentration. However, in Series I-2 solids were mainly accumulated at the bottom bed and above the second internal. This fact suggests char particles are being accumulated at the upper part due to the different solids distribution caused by the presence of the internals, as well as the accumulation of solids in a position close to the reactor exit [25]. This situation could facilitate the elutriation of char particles, decreasing their residence time in the fuel reactor. The solids stream leaving the fuel reactor would be concentrated in char, which entails that the char separation efficiency decreases inside the carbon stripper [31]. This behaviour was predicted by modelling the implementation of internals in the fuel reactor [24].

In Series I-3 the secondary flow was removed, and all the gas was fed by the distributor plate of the fuel reactor. As a consequence, the amount of solids in the fuel reactor decreased due to a higher gas velocity in the bottom part, and also the fraction of solids at the upper region was lower; see Table 4. Solids were still accumulated above the second internal (see Fig. 4) which can justify the lower $\mathrm{CO}_{2}$ capture rates compared to Series R. But a temperature gradient was observed which could explain the higher $\mathrm{CO}_{2}$ capture rate achieved in Series I-3 compared to Series I-2.

From these results, it can be stated that the use of ring-type internals in the fuel reactor decreases the $\mathrm{CO}_{2}$ capture rate because of accumulation of solids in a position close to the reactor exit. A highly efficient carbon stripper would be required to recover the high $\mathrm{CO}_{2}$ capture efficiency reached in Series $\mathrm{R}$. 
Submitted, accepted and published by

Fuel 250 (2019) 8-16

\subsection{Total oxygen demand}

Series R (tests 1-6) were initially carried out with the original riser of the fuel reactor, i.e. without internals, in order to establish the combustion efficiency at the reference conditions. The effect of the implementation of constrictions inside the fuel reactor on the combustion efficiency will be made in a suitable way by comparing the results obtained in Series I-1, I-2 and I-3. Here, both the total oxygen demand, $\Omega_{\mathrm{T}}$, and the combustion efficiency in the fuel reactor, $\eta_{\mathrm{comb}, \mathrm{FR}}$, are the parameters used to evaluate the combustion efficiency of the CLC unit; see Eqs. (3) and (4). Fig. 5 shows that both $\Omega_{\mathrm{T}}$ and $\eta_{\text {comb,FR }}$ were affected by the presence of internals in the fuel reactor, as well as by variations of other operating conditions, such as the oxygen carrier to fuel ratio or the specific solids inventory in agreement with previous results obtained in this CLC facility [11]. If we pay attention to the values of the total oxygen demand, it was obtained an average value of $\bar{\Omega}_{\mathrm{T}}=$ $12 \%$ for tests performed without internals in the fuel reactor, i.e. Series R. In Series I-1, $\bar{\Omega}_{\mathrm{T}}$ increased to values about $18 \%$ although the internals were installed. However, it cannot be said that the presence of internals had a negative effect on total oxygen demand, but the increase in total oxygen demand was caused by other effects. Thus, both the oxygen carrier to fuel ratio and specific solids inventory were lower in Series I-1 $\left(\phi=0.9\right.$ and $\left.m_{F R}^{*} \approx 250 \mathrm{~kg} / \mathrm{MW}_{\mathrm{th}}\right)$ compared to Series $\mathrm{R}(\phi$ $=1.3$ and $\left.m_{F R}^{*} \approx 400-500 \mathrm{~kg} / \mathrm{MW}_{\mathrm{th}}\right)$, which it is well known to affect negatively to the oxygen demand [11,32]. But more interestingly is the analysis of the solids distribution in the fuel reactor; see Fig. 4. At conditions used in Series I-1, i.e. low solids inventory and low gas velocity in the bottom part, most of solids were in this region. Low presence of solids in the upper part of the reactor was observed, where the internals were installed. Therefore, solids were not accumulated above the internals and could not be effective for the fuel oxidation.

In order to achieve similar solids inventories than in Series R, more solids were added to the CLC unit. Thus, Series I-2 was performed with the similar $\phi$ and $m_{F R}^{*}$ values than in Series R. Comparing 
Submitted, accepted and published by

Fuel 250 (2019) 8-16

results obtained in these Series, it can be observed a decrease in the average value of the total oxygen demand from $\bar{\Omega}_{\mathrm{T}}=12.2 \%$ without internals to $\bar{\Omega}_{\mathrm{T}}=9.8 \%$. This means an average decrease of $20 \%$ in the oxygen demand with the implementation of the internals in the fuel reactor. This value is in line with the potential $\Omega_{\mathrm{T}}$ reduction predicted by implementing internals in the fuel reactor [24]. In Series R and I-2, the oxygen carrier to fuel ratio was the same, and not only the amount of solids in the fuel reactor was similar but also the distribution of solids between the bottom and upper parts of the reactors was similar; see tests 3 and 10 in Fig. 4 . But there is a relevant difference in the solids distribution: while in Series $\mathrm{R}$ there is a uniform decrease in the solids concentration with the reactor height, in Series I-2 there is an accumulation of solids above the second internal, as it was expected considering fluid dynamics results from a cold flow model $[25,26]$. Likely, this fact promoted a better gas-solid contact at the upper part of the reactor, which enhanced the conversion of unburned gases in this section.

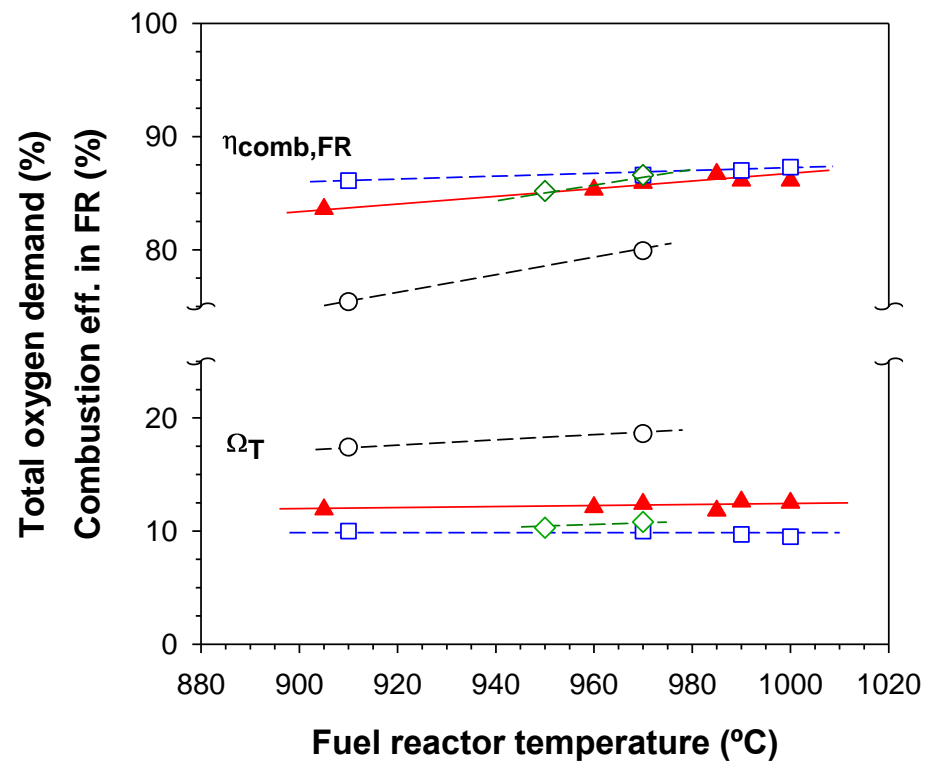

Fig. 5. Total oxygen demand and combustion efficiency in the fuel reactor as a function of the fuel reactor temperature for tests conducted without internals (Series R: $-\longrightarrow$ ) and with internals (Series I-1: -O- ;I-2: - $\left.--^{\prime} ; \mathrm{I}-3:-\diamond-\cdot\right)$. 
Submitted, accepted and published by

Fuel 250 (2019) 8-16

Then, solids at the bottom part of the reactor seems to be less effective oxidizing gasification products, as it was predicted from modelling results [14,32,33]. In order to decrease the amount of solids in the bottom part, the gas flow from the distributor plate was increased from 7 to $10 \mathrm{~m}^{3} / \mathrm{h}$ (STP), avoiding the secondary gas flow. As a result, the amount of solids both in the bottom and upper parts decreased, as well as the solids circulation rate. But accumulation of solids above the second internal was still observed; e.g. see test 14 in Fig 4. Thus, the total oxygen demand increased from $\bar{\Omega}_{\mathrm{T}}=9.8 \%$ in Series I-2 to $\bar{\Omega}_{\mathrm{T}}=10.5 \%$ in Series I-3. Interesting is the fact that the total oxygen demand in Series I-3 was still lower than in Series R, suggesting that the performance was improved by the use of internals even when there were lower values of $\phi$ and $m_{F R}^{*}$.

As it was shown, the total oxygen demand decreased with the use of internals in the CLC unit. However, one can think that these results could be influenced by a lower char conversion in the fuel reactor, related to a lower $\mathrm{CO}_{2}$ capture when the internals were installed; see Fig. 3 and Table 3. To evaluate this issue, it is interesting to analyse the evolution of $\Omega_{\mathrm{T}}$ jointly to $\eta_{\text {comb,FR }}$ as the char conversion in the fuel reactor varied, following a method previously developed [7]. In the four Series carried out in this work the total oxygen demand, $\Omega_{\mathrm{T}}$, was barely affected by the fuel reactor temperature. This means that the flow of unburnt products were roughly the same regardless the temperature in the reactor. However, the combustion efficiency in the fuel reactor, $\eta_{\text {comb,FR, }}$ showed a slight increase with the fuel reactor temperature. This means that the gases generated in the fuel reactor, i.e. volatile matter and char gasification products, are better oxidized as the temperature was higher. The different trend between $\Omega_{\mathrm{T}}$ and $\eta_{\text {comb,FR }}$ is related to the different oxidation degree of volatile matter and char gasification products. The amount of char gasification products increased with temperature, as the char conversion in the fuel reactor increased. Thus, an increase of $\eta_{\text {comb,FR }}$ with temperature would be related to a better combustion of char gasification products compared to volatile matter. In this way, if most of unburnt products were from volatile matter, $\Omega_{\mathrm{T}}$ would be 
Submitted, accepted and published by

Fuel 250 (2019) 8-16

roughly constant, as it is. Considering the values of $\Omega_{\mathrm{T}}, \Omega_{\mathrm{FR}}$ and $x_{\text {char,FR }}$ in Table 3 , the combustion efficiency of volatile matter, $\eta_{\text {comb, },}$, and char gasification products, $\eta_{\text {comb,g }}$, can be calculated from the following expression [7]:

$$
A=\left(1-\eta_{c o m b, v}\right)+\left(1-\eta_{c o m b, g}\right) \cdot B \quad \text { with } A=\frac{\Omega_{c h a r}\left(1-x_{c h a r, F R}\right)}{\Omega_{v o l}\left[\frac{1}{\Omega_{T}}-\frac{1}{\Omega_{F R}}\right]} \quad \text { and } \quad B=\frac{\Omega_{c h a r}}{\Omega_{v o l}} x_{c h a r, F R}
$$

Fig. 6 shows the B vs. A plot and the corresponding linear regression by least squares approximation. Results of the combustion efficiency of volatile matter and char gasification products are shown in Table 5. The uncertainty of these values may be high due to the lack of a relevant number of available results. Note that in some cases two data are only used for the regression. However, when all the results obtained in this work are evaluated together, additional information about the combustion of volatile matter and gasification products can be extracted from this analysis, which can be compared to other results, e.g. the conversion of methane.

As expected from the previous discussion, a high combustion degree of char gasification products is calculated, with values of $\eta_{\text {comb,g }}$ above $90 \%$ in all Series. Lower is the combustion efficiency of volatile matter, which is also affected by the presence of internals in the fuel reactor. Thus, $\eta_{\text {comb,v }}$ values of 67.1 and $51.1 \%$ are calculated for Series $\mathrm{R}$ and $\mathrm{I}-1$, i.e. where there was no either internals or accumulation of solids above the internals. Then, the presence of internals caused an increase in the combustion efficiency of volatile matter, but higher for Series I-2 $\left(\eta_{\text {comb,v }}=78.3 \%\right)$ than for Series I-3 $\left(\eta_{\text {comb,v }}=70.6 \%\right)$ due to the different values of $\phi$ and $m_{F R}^{*}$; see Table 2 .

Considering $\mathrm{CH}_{4}$ as a marker of volatile matter content, it is observed that most of the contribution to the total oxygen demand is due to the presence of this gas; see Table 3 . The conversion of $\mathrm{CH}_{4}$ in the fuel reactor was calculated assuming the generation of $0.0704 \mathrm{~kg} \mathrm{CH}_{4}$ per $\mathrm{kg}$ of coal [34], and it is shown in Tables 3 and 5. In general, the methane conversion has the trend followed by $\eta_{\text {comb,v }}$, and it is improved by the presence of internals. 
Submitted, accepted and published by

Fuel 250 (2019) 8-16

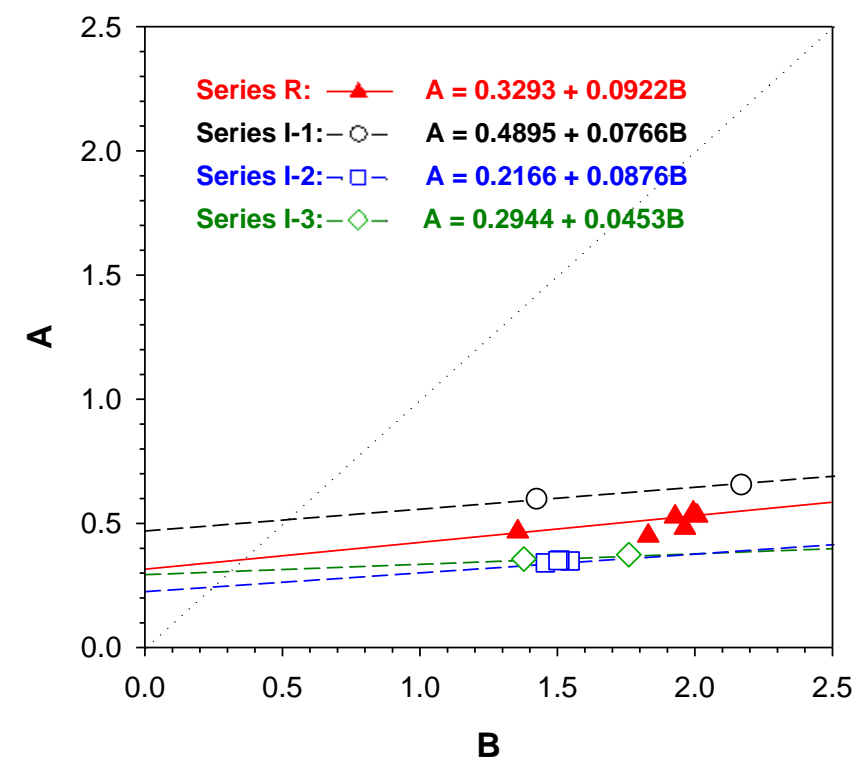

Fig. 6. Determination of combustion efficiency of volatile matter and gasification products following Eq. (6) for the four Series carried out in this work.

Table 5. Values of combustion efficiency of gasification products, $\eta_{\text {comb,g }}$, and volatile matter, $\eta_{\text {comb,v }}$, according to Eq. (6) and results shown in Fig. 6, and $\mathrm{CH}_{4}$ conversion.

\begin{tabular}{cccc}
\hline Series & $\begin{array}{c}\eta_{\text {comb,g }} \\
(\%)\end{array}$ & $\begin{array}{c}\eta_{\text {comb,v }} \\
(\%)\end{array}$ & $\begin{array}{c}\bar{X}_{C_{4}} \\
(\%)\end{array}$ \\
\hline $\mathrm{R}$ & 90.8 & 67.1 & 52.3 \\
\hline $\mathrm{I}-1$ & 92.3 & 51.1 & 45.7 \\
\hline $\mathrm{I}-2$ & 91.2 & 78.3 & 61.6 \\
\hline $\mathrm{I}-3$ & 95.5 & 70.6 & 66.6 \\
\hline
\end{tabular}

The different combustion efficiency of volatile matter and gasification products can be explained because of differences on reactivity and gas-solid mixing, as it was previously discussed in works modelling the fuel reactor behaviour [14,35]. Char particles are well mixed with oxygen carrier particles. Therefore, char gasification products $\left(\mathrm{CO}\right.$ and $\left.\mathrm{H}_{2}\right)$ are mainly generated in the emulsion phase, where can easily react with ilmenite particles. However, volatile matter is mainly evolved in bubbles or plumes in the bottom region with poor contact with oxygen carrier particles. The gas- 
Submitted, accepted and published by

Fuel 250 (2019) 8-16

solid contact is somewhat improved in the dilute region, where is mainly converted. In this line, the presence of internals enhances the gas-solid contact in the dilute region. In addition, low values of $\mathrm{H}_{2}$ are detected in the presence of internals, which is related to the high reactivity of this gas with ilmenite compared to reactivity with $\mathrm{CO}$ or $\mathrm{CH}_{4}$ [36]. In this sense, the low reactivity of ilmenite with $\mathrm{CH}_{4}$ justifies the high fraction of total oxygen demand coming from $\mathrm{CH}_{4}$. Because of this, the effect of internals on the fluid dynamics of the fuel reactor improves the combustion efficiency of the CLC process.

It was determined that the volatile matter was more difficult to oxidize than the char gasification products, and the enhancement of the gas-solid contact is a relevant issue to promote the conversion of volatile matter. This fact can be of high relevance with fuels with a high volatile content, such as biomass. In this case, the combustion efficiency could be improved by implementing internals but without negatively affect to the $\mathrm{CO}_{2}$ capture due to the high reactivity of char from biomass. This hypothesis will be evaluated in future works with biomass as fuel. In addition, the potential of using ring-type internals on the improvement of the combustion efficiency could be higher in CLC units with taller fuel reactors, as it was predicted from modelling results [24]. However, the studies carrier out about the effects of internals on the reactor fluid dynamics is mostly restricted to cold flow models [25-27]. The potential of this solution at large-scale should be evaluated during the scale-up of the CLC process, considering technological options in order to disturb the core-annulus structure of the circulating fluidized bed and distributing the solids along the riser.

\section{Conclusions}

Two experimental campaigns were conducted in the continuously operated $50 \mathrm{~kW}_{\text {th }}$ CLC pilot plant for solid fuels to evaluate the effect of ring-type internals in the fuel reactor on the performance of coal combustion by CLC. The presence of internals modified the solids distribution in the fuel reactor, which affected to the total oxygen demand. The presence of the internals had a beneficial 
Submitted, accepted and published by

Fuel 250 (2019) 8-16

effect on the coal combustion. Thus, the total oxygen demand decreased from $12.2 \%$ to $9.8 \%$, corresponding to a decrease of $20 \%$. It was concluded that conversion of volatile matter was improved by the presence of the internals, because the conversion of $\mathrm{CH}_{4}$ was improved up to $25 \%$. Also, gasification products were highly converted, as shown the fact that very low $\mathrm{H}_{2}$ concentration values were achieved.

\section{Acknowledgements}

This work was supported by the Spanish Ministry of Economy, Industry and Competitiveness (projects ENE2014-56857-R and ENE2016-77982-R), the Spanish National Research Council (CSIC project: 2017-80E035), the EU project ACCLAIM (RFCP-CT-2012-00006) and the European Regional Development Fund (ERDF). 
Submitted, accepted and published by

Fuel 250 (2019) 8-16

\section{Nomenclature}

$F_{i} \quad$ molar flow of compound $i(\mathrm{~mol} / \mathrm{s})$

$F_{C, \text { elut }} \quad$ carbon flow in the char elutriated (mol C/s)

$\dot{m}_{O C} \quad$ solids circulation flow rate $(\mathrm{kg} / \mathrm{s})$

$m_{F R}^{*} \quad$ specific solids inventory into the fuel reactor $(\mathrm{kg} / \mathrm{MW}$ th

$\dot{m}_{s f} \quad$ rate of solids feeding $(\mathrm{kg} / \mathrm{s})$

$R_{o c} \quad$ oxygen transport capacity of the oxygen carrier ( $\mathrm{kg}$ oxygen per $\mathrm{kg}$ oxygen carrier)

$T \quad$ temperature $\left({ }^{\circ} \mathrm{C}\right)$

$u_{g} \quad$ gas velocity $(\mathrm{m} / \mathrm{s})$

$X_{\mathrm{CH}_{4}} \quad$ methane conversion (-)

$x_{c h a r, F R}$ fraction of carbon in char converted in the fuel reactor (-)

$X_{s f} \quad$ solid fuel conversion to gas (-)

$x_{C} \quad$ carbon fraction in coal (-)

$x_{f c} \quad$ fixed carbon in coal (-)

Greek symbols

$\triangle P \quad$ pressure drop $(\mathrm{Pa})$

$\Delta T_{\text {upper-bottom }}$ temperature difference between the upper and the bottom parts of the fuel reactor $\left({ }^{\circ} \mathrm{C}\right)$

$\phi \quad$ oxygen carrier-to-fuel ratio (-)

$\eta_{\mathrm{CC}} \quad \mathrm{CO}_{2}$ capture efficiency (-)

$\eta_{\text {comb,FR }}$ combustion efficiency in the fuel reactor (-)

$\eta_{\text {comb,v }}$ combustion efficiency of the volatile matter (-)

$\eta_{\text {comb,g }}$ combustion efficiency of the char gasification products (-)

$\Omega_{\text {char }} \quad$ oxygen demand of char (kg oxygen per kg solid fuel)

$\Omega_{\mathrm{sf}} \quad$ oxygen demand of the coal (kg oxygen per $\mathrm{kg}$ solid fuel)

$\Omega_{\mathrm{FR}} \quad$ oxygen demand in the fuel reactor (-)

$\Omega_{\mathrm{T}} \quad$ total oxygen demand (-)

$\Omega_{\mathrm{vol}} \quad$ oxygen demand of volatile matter ( $\mathrm{kg}$ oxygen per $\mathrm{kg}$ solid fuel)

Acronyms

AR Air reactor

CCS Carbon capture and Storage

CLC Chemical Looping Combustion

CLOU Chemical Looping with Oxygen Uncoupling

FR Fuel reactor

$i$ G-CLC in-situ Gasification Chemical Looping Combustion

LHV Lower Heating Value $(\mathrm{kJ} / \mathrm{kg})$

OC Oxygen carrier

XRD X-Ray Diffraction 
Submitted, accepted and published by

Fuel 250 (2019) 8-16

\section{References}

[1] International Energy Agency (IEA). World Energy Outlook. Executive summary 2017. Paris, France.

[2] Bui M, Adjiman CS, Bardow A, Anthony EJ, Boston A, et al. Carbon capture and storage (CCS): the way forward. Energy Environ Sci 2018;11:1062-176.

[3] Ekström C, Schwendig F, Biede O, Franco F, Haupt G, de Loeijer G, Papapavlou C, Røkke, PE. Techno-economic evaluations and benchmarking of pre-combustion $\mathrm{CO}_{2}$ capture and oxy-fuel processes developed in the European ENCAP project, Energy Procedia 2009; 1:423340.

[4] Ishida M, Jin H. A new advanced power-generation system using Chemical-Looping Combustion. Energy 1994;19:415-22.

[5] Lyngfelt A, Leckner B, Mattisson T. A fuidized-bed combustion process with inherent $\mathrm{CO}_{2}$ separation; application of chemical-looping combustion. Chem Eng Sci 2001;56:3101-13.

[6] Adanez J, Abad A, Garcia-Labiano F, Gayan P, de Diego LF. Progress in Chemical-Looping Combustion and Reforming Technologies. Prog Energy Combust Sci 2012;38:215-82.

[7] Adánez J, Abad A, Mendiara T, Gayán P, de Diego LF, García-Labiano F. Chemical looping combustion of solid fuels. Prog Energy Combust Sci 2018;65:6-66.

[8] Dennis JS, Scott SA. In situ gasification of lignite coal and $\mathrm{CO}_{2}$ separation using chemical looping with a Cu-based oxygen carrier. Fuel 2010;89:1623-40.

[9] Markström P, Linderholm C, Lyngfelt A. Chemical-looping combustion of solid fuels design and operation of a $100 \mathrm{~kW}$ unit with bituminous coal. Int J Greenhouse Gas Control 2013;15:150-62.

[10] Shen L, Wu J, Gao Z, Xiao J. Characterization of chemical looping combustion of coal in a 1 $\mathrm{kW}_{\text {th }}$ reactor with a nickel-based oxygen carrier. Combust Flame 2010;157:934-42.

[11] Pérez-Vega R, Abad A, García-Labiano F, Gayán P, de Diego LF, Adánez J. Coal combustion in a $50 \mathrm{~kW}_{\text {th }}$ Chemical Looping Combustion unit: Seeking operating conditions to maximize $\mathrm{CO}_{2}$ capture and combustion efficiency. Int J Greenhouse Gas Control 2016;50:80-92.

[12] Ma J, Tian X, Wang C, Chen X, Zhao H. Performance of a $50 \mathrm{~kW}_{\text {th }}$ coal-fuelled chemical looping combustor. Int J Greenhouse Gas Control 2018;75:98-106.

[13] Lyngfelt A, Leckner B. A $1000 \mathrm{MW}_{\text {th }}$ boiler for chemical-looping combustion of solid fuels Discussion of design and costs. Appl Energy 2015;157:475-87.

[14] García-Labiano F, de Diego LF, Gayán P, Abad A, Adánez J. Fuel reactor modelling in chemical-looping combustion of coal: 2-simulation and optimization. Chem Eng Sci 2013;87:173-82.

[15] Cabello A, Gayán P, Abad A, de Diego LF, García-Labiano F, Izquierdo MT, Scullard A, Williams G, Adánez J. Long-lasting Cu-based oxygen carrier material for industrial scale in Chemical Looping Combustion. Int J Greenhouse Gas Control 2016;52:120-9.

[16] Hauss J, Hartge EU, Werther J, Heinrich S. Effects of a Two-Stage Fuel Reactor on Chemical Looping Combustion with Methane, Bituminous Coal, Lignite and Wood Biomass. In proceedings of the $5^{\text {th }}$ Int Conf Chemical Looping 2018, Park City, Utah, USA.

[17] Pérez-Vega R, Abad A, García-Labiano F, Gayán P, de Diego LF, Izquierdo MT, Adánez J. Chemical Looping Combustion of gaseous and solid fuels with manganese-iron mixed oxide as oxygen carrier. Energy Convers Manage 2018;159:221-31.

[18] Pérez-Vega R, Gayán P, Izquierdo MT, Abad A, García-Labiano F, de Diego LF, Adánez J. Development of magnetic Mn-Fe support materials for CLC applications. In proceedings of the $5^{\text {th }}$ Int Conf Chemical Looping 2018, Park City, Utah, USA.

[19] Cuadrat A, Abad A, Gayán P, de Diego LF, García-Labiano F, Adánez J. Theoretical approach on the CLC performance with solid fuels: Optimizing the solids inventory. Fuel 
Submitted, accepted and published by

Fuel 250 (2019) 8-16

2012;97:536-51.

[20] Thon A, Kramp M, Hartge EU, Heinrich S, Werther J. Operational experience with a system of coupled fluidized beds system for chemical looping combustion of solid fuels using ilmenite as oxygen carrier. Appl Energy 2014;118,309-17.

[21] Yan J, Shen L, Jiang S, Wu J, Shen T, Song T. Combustion Performance of Sewage Sludge in a Novel CLC System with a Two-Stage Fuel Reactor. Energy Fuels 2017;31:12570-81.

[22] Song T, Shen L. Review of reactor for chemical looping combustion of solid fuels. Int J Greenhouse Gas Control 2018;76:92-110.

[23] Kempkes V, Kather A. Chemical looping combustion: comparative analysis of two overall process configurations for removing unburned gaseous compounds. In proceedings of the $2^{\text {nd }}$ Int Conf Chemical Looping 2012; Darmstadt, Germany.

[24] Gayán P, Abad A, de Diego LF, García-Labiano F, Adánez J. Assessment of technological solutions for improving chemical looping combustion of solid fuels with $\mathrm{CO}_{2}$ capture. Chem Eng J 2013;233:56-69.

[25] Penthor S, Stollhof M, Pröll T, Hofbauer H. Detailed fluid dynamic investigations of a novel fuel reactor concept for chemical looping combustion of solid fuels. Powder Technol 2016;287:61-9.

[26] Guío-Pérez DC, Hofbauer H, Pröll T. Effect of Ring-Type Internals on Solids Distribution in a Dual Circulating Fluidized Bed System - Cold Flow Model Study. AIChE J 2013;59:361223.

[27] Bu J, Zhu J-X. Influence of Ring-Type Internals on Axial Pressure Distribution in Circulating Fluidized Bed. Canadian J Chem Eng 1999;77:26-34.

[28] Cuadrat A, Abad A, García-Labiano F, Gayán P, de Diego LF, Adánez J. Relevance of the coal rank on the performance of the in situ gasification chemical-looping combustión. Chem Eng J 2012;195-196:91-102.

[29] Ohlemüller P, Alobaid F, Abad A, Adanez J, Ströhle J, Epple B. Development and validation of a $1 \mathrm{D}$ process model with autothermal operation of a $1 \mathrm{MW}_{\mathrm{th}}$ chemical looping pilot plant. Int J Greenhouse Gas Control 2018;73:29-41.

[30] Abad A, Pérez-Vega R, de Diego LF, García-Labiano F, Gayán P, Adánez J. Design and operation of a $50 \mathrm{~kW}_{\text {th }}$ Chemical Looping Combustion (CLC) Unit for Solid Fuels. Appl Energy 2015;157:295-303.

[31] Cheng M, Sun H, Li Z, Cai N. Annular Carbon Stripper for Chemical-Looping Combustion of Coal. Ind Eng Chem Res 2017;56:1580-93.

[32] Abad A, Adánez J, de Diego LF, Gayán P, García-Labiano F, Lyngfelt A. Fuel reactor model validation: Assessment of the key parameters affecting the chemical-looping combustion of coal. Int J Greenhouse Gas Control 2013;19:541-51.

[33] Abad A, Gayán P, García-Labiano F, de Diego LF, Adánez J. Relevance of plant design on CLC process performance using a Cu-based oxygen carrier. Fuel Process Technol 2018;171:78-88.

[34] Matthesius GA, Morris RM, Desai MJ. Prediction of the volatile matter in coal from ultimate and elemental analyses. J S Afr Inst Min Mett 1987;87:157-61.

[35] Abad A, Gayán P, de Diego LF, García-Labiano F, Adánez J. Fuel reactor modelling in chemical-looping combustion of coal: 1. model formulation. Chem Eng Sci 2013;87:277-93.

[36] Abad A, Adánez J, Cuadrat A, García-Labiano F, Gayán P, de Diego LF. Kinetics of redox reactions of ilmenite for chemical-looping combustion. Chem Eng Sci 2011:66;689-702. 